УДК 37(091) (477)

DOI: 10.37026/2520-6427-2021-106-2-12-15
Тетяна СОРОЧИНСЬКА, кандидат педагогічних наук, доиент кафедри філософіі

Рівненського державного гуманітарного університету, м. Рівне, Україна

ORCID: 0000-0002-0912-8663

e-mail: sorochinska1975@gmail

\title{
ІДЕАЛ УЧИТЕЛЯ: ПОРІВНЯННЯ ОСВІТНІХ ІДЕЙ РАДЯНСЬКОГО ПЕРІОДУ ТА СУЧАСНОСТІ
}

\begin{abstract}
Анотація. У статті здійснено спробу порівняльного аналізу ідеалу вчителя та освітніх ідей радянського періоду і сучасності. Висвітлено педагогічну кониепиію освітнього ідеалу повоєнних років. Схарактеризовано основні складові та вимоги до професійноі майстерності сучасного фахівия. Обгрунтовано ідею самовиховання як необхідну передумову набуття $i$ збереження професіоналізму вчителя, зокрема розглянуто основні характеристики педагога-початківия та педагога-майстра, окреслено, як майбутній учитель з об'єкта виховного впливу ( «Я-студент, нехай мене вчать») перетворюється на суб'єкт організації власної життєдіяльності («Я-майбутній педагог, готую себе до педагогічної діяльності щоденно»).

Використовуючи педагогічний досвід відомих педагогів, розкрито сутність професійної індивідуальності
\end{abstract}

вчителя та педагогічної культури як вирішального елемента формування його педагогічної майстерності. Доведено, що індивідуальна педагогічна культура виявляється у професійній поведіниі педагога. У контексті розкриття проблеми представлено погляд на вчителя з високим і низьким рівнем педагогічної культури, обтрунтовано поняття «педагогічного безкультур'я» як неуитва та обмеженості педагога. Зосереджено увагу на гуманістичній установці вчителя, щуо визначає стратегію і тактику освітнього прочесу, а також на духовно-моральній складовій як основі педагогічної діяльності майбутнього фахівия.

Ключові слова: ідеал учителя, педагогічні ідеї, вітчизняний досвід, професійна майстерність, самовиховання, педагогічна культура.

\author{
Tatiana SOROCHYNSKA, \\ PhD in Pedagogy, \\ Associate Professor of Philosophy \\ Rivne State University of Humanities, \\ Rivne, Ukraine \\ ORCID:0000-0002-0912-8663 \\ e-mail: sorochinska1975@gmail
}

\section{TEACHER'S IDEAL: COMPARISON OF EDUCATIONAL IDEAS OF THE SOVIET PERIOD AND THE MODERNITY}

\begin{abstract}
The article attempts comparative analysis of the teacher's ideal and educational ideas of the Soviet period and modernity. In particular, the pedagogical concept of the educational ideal of the postwar years is highlighted, as well as the main components and requirements for the professional skills of a specialist at the present stage of development of education in Ukraine are characterized. The idea of self-education as a necessary prerequisite for the acquisition and preservation of teacher professionalism is revealed; the main characteristics of a novice teacher and a master teacher are considered; as a future teacher from the object of educational influence ("I am a student, let me be taught») should become a subject of organization of their own lives ("I am a future teacher, I prepare myself for teaching every day»).

Using the pedagogical experience of famous teachers, the essence of the professional individuality
\end{abstract}

of the teacher, pedagogical culture as a crucial element in the formation of his pedagogical skills is revealed. It is proved that the individual pedagogical culture is manifested in the professional behavior of the teacher. In the context of solving the problem, a teacher with a high and low level of pedagogical culture is reflected. The concept of "pedagogical lack of culture» as ignorance and limitations of the teacher is substantiated. The focus is on the humanistic attitude of the teacher, which determines the strategy and tactics of the educational process; on the spiritual and moral component as the basis of pedagogical activity of the future specialist; on the partner subject-subject interaction as the organization of educational process (in particular, it is noted that an important quality of a teacher is the ability to move away from the authoritarian format and be equal to children); on the study and implementation of advanced pedagogical 
experience. The opinion is revealed that in order to achieve the desired pedagogical ideal (both for the Soviet teacher and the modern one) experience is important - the basis on which the pedagogical skill of the teacher grows.

Key words: the ideal of the teacher, pedagogical ideas, domestic experience, professional skill, selfeducation, pedagogical culture.

Постановка проблеми. Кожен історично визначений час залишає по собі характерне для нього розуміння ідеалу вчителя - особистості, яка не тільки володіє системою знань, адекватною в науковій картині світу певного періоду, а й власною системою цінностей, самостійністю в думках та вчинках; людини, відкритої до діалогу і творення культури шляхом діалогічного спілкування, обміну смислами культурного саморозвитку. Саме тому предметом нашого зацікавлення є питання порівняльного аналізу освітніх ідей та ідеалу вчителя радянського періоду й сучасності.

Філософія вчителя і вимоги до нього змінюються разом із реформою освіти. Зрозуміло, що сучасний рівень усвідомлення школи та учня постійно потребує нових підходів до розуміння суті професійної індивідуальності вчителя, психолого-педагогічних умов іiі становлення, адже кожен учитель має усвідомлювати свою особистісну і професійну сутність, місце і призначення у навчальному закладі, готовність до безперервного професійного самовдосконалення. Він має осмислювати зміст і значення моральних вимог суспільства, самостійно оцінювати як власні вчинки, так і дії вихованців, розуміти, що таке обов'язок, відповідальність, совість, гідність, а також мати тверді переконання щодо самооцінки і самовиховання.

Аналіз наукових досліджень і публікацій. Грунтовний аналіз професійної підготовки радянського вчителя в контексті освітніх реформ повоєнних років у своїх монографіях здійснили О. Антонова, Л. Березівська, С. Вітвицька, В. Доброчинська, О. Дубасенюк, О. Петренко, Т. Семенюк та ін. Різні аспекти професійного становлення і саморозвитку вчителя, формування його педагогічної майстерності, вдосконалення технологій навчання майбутнього фахівця означеного періоду розкрито в роботах О. Абдуліної, М. Антонця, С. Білецької, Л. Бондара, В. Бутенка, В. Василенка, Н. Василенка, М. Костенка, А. Луцюка, А. Розенберга, Л. Сіднєвої, М. Сметанського, О. Химченко, К. Юр'євої та ін.

Мета статті - здійснити порівняльний аналіз ідеалу вчителя та освітніх ідей радянського повоєнного періоду та сучасності.

Виклад основного матеріалу дослідження. У контексті досліджуваної проблеми відмітимо, що в період «хрущовської відлиги» був сформований педагогічний ідеал людини: гармонійно розвиненої, творчої особистості, інтелектуально багатої, працелюбної, культурної, яка вміє поєднувати особистісні потреби із суспільними вимогами. Важливим у зв'язку з цим $€$ той аспект, що нова марксистсько-ленінська етика визнавала особистість і особистісні інтереси конкретної людини, а не лише інтереси колективу (Петренко, 2010, с. 297-298).

Слід наголосити, що для радянського періоду було характерне виникнення і розвиток низки педагогічних ідей, як-от: А. Макаренка (технологія іміджу особистості педагога, трудове виховання) у 1920-1930-х рр.; Л. Гордіна, А. Кондратюка (концепція педагогічного стимулювання) у 1940-1960-х рр.; Г. Ващенка (концепція логічного мислення і творчої фантазії); В. Давидова, Д. Ельконіна (розвивальне навчання); I. Лернера (створення проблемних ситуацій); В. Сухомлинського (концепція самовиховання, ідея всебічного й гармонійного розвитку особистості); І. Ткаченка (політехнічне навчання і трудове виховання); М. Данилова, М. Скаткіна, Б. Ссипова (самостійність і творча ініціатива учнів); Ю. Шарова (формування духовних потреб особистості); Г. Щукіної (концепція пізнавального інтересу) та ін.

На думку В. Сухомлинського, «необхідною передумовою набуття і збереження професіоналізму вчителя $є$ самовиховання - систематична і свідома діяльність людини, спрямована на вироблення в собі бажаних фізичних, розумових, моральних, естетичних якостей, позитивних рис, волі й характеру, усунення негативних звичок; формування людиною своєї особистості відповідно до свідомо поставленої мети» (Сухомлинський, 1976, с. 419-654).

Для педагога робота над собою - обов'язкова передумова набуття і збереження професіоналізму, внаслідок чого майбутній учитель з об'єкта виховного впливу («Я - студент, нехай мене вчать») повинен перетворитися на суб'єкт організації власної життєдіяльності («Я - майбутній педагог, готую себе до педагогічної діяльності щоденно»).

Сьогодні, як і сто років тому, головною рисою вчителя, його «моральною серцевиною» залишається любов до дітей (адже відомо, що діти охоче навчаються лише в того, кого люблять і поважають) та вміння відійти від авторитарного формату і бути на рівні 3 ними. Саме здатність ставитися до дітей як до рівних дає вчителеві змогу навчитися від них не менше, ніж вони навчаться від нього. Місія сучасного вчителя i школи - навчити дітей бути гнучкими у змінах, легко адаптуватися до непередбачуваних ситуацій, вчитися впродовж усього життя. Щоб досягти цього, вчителеві потрібно бути зразком для своїх учнів.

Проведений компаративний аналіз дозволяє стверджувати, що завдання, які ставилися перед радянським учителем у повоєнні роки, були набагато складнішими від тих, що ставляться перед ним сьогодні. Насамперед педагог змушений був адаптуватися сам та адаптувати дітей до важких умов повоєнного життя, надати їм психологічну й моральну підтримку, і лише після цього навчати їх, передаючи знання, вміння і навички. За таких умов важливим був педагогічний досвід учителя - творче, активне засвоєння і реалізація ним у практичній діяльності засобів і принципів педагогіки, педагогічної майстерності з урахуванням конкретних умов, особливостей дітей та учнівського колективу (Любар, Стельмахович, Федоренко, 2006). Отож для досягнення бажаного педагогічного ідеалу (як для радянського вчителя, так і сучасного) важливим є досвід. Це основа, на якій грунтується педагогічна майстерність учителя.

Вивчення, узагальнення і поширення передового педагогічного досвіду та впровадження досягнень психолого-педагогічної науки в практику - важливі 
завдання педагогіки, які є основою інноваційних процесів в освіті. Результатом цих процесів $є$ використання теоретичних і практичних нововведень, що формувалися на межі теорії і практики. За цих обставин учитель виступає автором, дослідником, користувачем та пропагандистом нових педагогічних теорій, технологій, концепцій. Не виключення - і радянський період, для якого була характерна надмірна політизація освіти, що виявлялася в ідейно-політичній заангажованості навчального процесу в усіх без винятку освітніх закладах УРСР, яка суттєво знижувала рівень реалізації та розвитку професійних і творчих здібностей учителя. Ми поділяємо точку зору О. Дубасенюк стосовно того, що розвиток інновацій у 1940-і роки визначався ідеологічними принципами і партійними постановами, які спричиняли уніфікацію освіти та стримували інноваційний рух: на тлі ідеології соціалізму постала педагогічна система, основними ідеями якої було формування радянської людини в умовах соціалістичного середовища, колективістське виховання, свідома дисципліна, поєднання поваги і відповідальності тощо.

Із початком «хрущовської відлиги» в радянському суспільстві розпочалася нова епоха - інновацій в освіті, домінантою якої стали гуманістичні ідеї В. Сухомлинського щодо необхідності піднесення людини як найвищої соціальної цінності, формування національної і людської гідності у школярів, розвиток творчих здібностей особистості на основі етичних цінностей та партнерської суб'єкт-суб'єктної взаємодії (Дубасенюк, 2011). У зв'язку з цим важливим етапом на шляху до суб'єкт-суб'єктних відносин стало застосування в освітньому процесі педагогічних засобів, спрямованих на стимулювання активної суб'єктної позиції того, хто навчається, створення такого мікроклімату, аби розвиток особистості відбувався у процесі власної діяльності через осмислення цієї діяльності й себе в ній у діалогічному емоційному контакті з іншою людиною.

Вітчизняна система шкільної освіти має неабиякі надбання, але вона не враховує індивідуальної специфіки особистості: тип темпераменту, здібності, характер, особливості сприйняття, мислення, пам'яті, уваги, емоцій і почуттів, уяви тощо. Індивідуальна навчальна траєкторія кожної особистості, як правило, залишається поза увагою педагога радянської школи. Найкращі результати навчальної діяльності з'являються тоді, коли дії педагога збігаються з власним зусиллям учня щодо своєї освіти. Виникає явище синхронізації суб'єкт-суб' єктних відносин, своєрідний «педагогічний резонанс», що змінює парадигму освіти: від абсолютизації зовнішнього впливу на учня до його поєднання iз процесом самостійних зусиль школяра (Київський університет імені Б. Грінченка: вебсайт, 2020).

Педагог вважається майстром лише тоді, коли він володіє професійними секретами, як-от: умінням перетворити кожного учня на активного суб'єкта освітнього процесу; забезпечити оптимальний варіант навчання, виховання і розвитку кожної дитини; варіативним підходом до визначення теми, мети, завдань, типу уроку; корекцією діяльності кожного учня, спрямуванням їі на пошук знань, досягнення повсякденного успіху; інструментарієм: знайти, підтримати, розвинути людину в людині, закласти в неї механізм самореалізації; високою культурою праці; наявністю взаємодії, емоційно-інтелектуальної спільності «педагог - учень»; творчим самопочуттям учителя і учня у процесі роботи на уроці, відчуттям задоволення від спільної праці та ін.

Вирішальним елементом формування професіоналізму вчителя $є$ педагогічна культура - сутнісна характеристика, що відображає динамічну систему професійних цінностей діяльності та поведінки. Вона $€$ синтезом високого професіоналізму та особистісних якостей педагога. Учителеві з високим рівнем педагогічної культури властиві теоретичне обгрунтування власної педагогічної позиції, системність педагогічної діяльності, творення, гнучкість і варіативність у прийнятті рішень. Такий педагог має індивідуальний стиль. Він не тільки зберігає і відтворює духовні цінності, а й сам створює їх у вигляді нових технологій, методик, дидактичних і виховних систем. I навпаки, в учителя з низьким рівнем професійної культури виявляється невпевненість, нестійкість власної позиції, безсистемність, непослідовність, невміння вирішувати педагогічні проблеми. У зв'язку з цим В. Сухомлинський неодноразово наголошував: «Педагогічне безкультур'я - неуцтво, де вчитель через свою обмеженість прагне перетворити дитячу беззахисність у клітку, куди він заганяє маленьке пташеня і робить 3 ним те, що йому заманеться. Нерозуміння дитячої беззахисності - одна 3 причин незавидного становища вчителя, який зрештою втрачає владу над дітьми» (Сухомлинський, 1964).

На відміну від освітнього ідеалу радянської епохи (покірної особи - провідника ідейності та партійних принципів), сучасний педагог є незалежним, творчим, ініціативним та креативним, взірцем професіонала, носієм високих громадянських, професійних, моральних i особистісних якостей. Збалансованість цих якостей, а також гармонійність прояву підтверджується впевненістю у власних знаннях, уважним і бережливим ставленням до дітей, повагою до їхніх почуттів. Сучасний учитель повинен уміти творчо застосовувати знання, критично осмислювати здобуту з різних джерел інформацію, слідкувати за досягненнями психолого-педагогічної науки, володіти інноваційними технологіями та інтерактивними методиками. Саме такий фахівець зможе забезпечити якісну освіту і дати оптимальний результат. Високий рівень педагогічної компетентності вчителя забезпечить його успішну орієнтацію у сучасному освітньому інформаційному просторі, задовольнить індивідуальні та професійні потреби, сприятиме досягненню успіху у професійному самовираженні та взаємодії з соціумом (Сорочинська, 2021, с.191).

Висновки. Здійснений нами порівняльний аналіз ідеалу сучасного вчителя і вчителя радянського періоду дає підстави стверджувати, що, незалежно від конкретних історичних умов епохи, людина, яка обрала професію вчителя, має бути наділена певними особливими якостями, що характеризують її як авторитетну особистість. Разом із тим, слід наголосити, що в наш час освітній ідеал учителя дещо змінився. Він передбачає як професіоналізм і загальну культуру педагога, так і його планетарне мислення, культурний плюралізм. Важливим $є$ й те, що перед освітою нині постала необхідність зміни ролі учителя в навчальному процесі, що зумовлено втратою ним домінуючої 
інформативної функції й посилення ролі співпраці й організації індивідуально векторизованої освіти.

Щодо освітніх ідей радянського періоду і сучасності, варто зауважити, що головною метою освіти завжди були і залишаються: всебічний розвиток особистості як найвищої цінності суспільства, їі талантів, розумових і фізичних здібностей; виховання високих моральних якостей; формування громадян, здатних до свідомого суспільного вибору, збагачення на цій основі інтелектуального, творчого, культурного потенціалу нації, підвищення іiі освітнього рівня, забезпечення держави кваліфікованими фахівцями.

Подальші наші дослідження плануємо спрямувати на розгляд проблеми професійної підготовки вчителя у контексті реформування освіти.

\section{СПИСОК ВИКОРИСТАНОЇ ЛІТЕРАТУРИ}

Петренко, О. Б. (2010). Гендерний вимір шкільної освіти в Україні (XX століття): монографія. Рівне: видавець О. Зень. 530 с.

Сухомлинський, В. О. (1976). Сто порад учителеві. Вибрані твори: в 5 т. Київ: Радянська школа. Т. 2. C. 419-654.

Любар, О. О., Стельмахович, М. Г., Федоренко, Д. Т. (2006). Історія української школи і педагогіки: навч. посіб. Київ: Знання. 647 с.

Дубасенюк, О. А. (2011). Упровадження освітніх інновацій в системі вищої освіти. Інновації у вищій освіті : проблеми, досвід, перспективи: монографія / за ред. П. Ю. Сауха. Житомир: Вид-во ЖДУ ім. І. Франка. С. $62-91$.

Київський університет імені Бориса Грінченка: вебсайт. URL: https://studfile.net/preview/5110217/ page:4/ (дата звернення: 23.12.2020).

Сухомлинський, В. О. (1964). Праця, покликання, щастя. Молодь України. 3 червня.

Сорочинська, Т. А. (2021). Професійна підготовка вчителя на Рівненщині в контексті освітніх реформ
1939-1964 років: монографія. Рівне: видавець О. Зень. $234 \mathrm{c}$.

\section{REFERENCES}

Petrenko, O. B. (2010). Hendernyi vymir shkilnoi osvity v Ukraini (XX st.) [Gender dimension of school education in Ukraine (XX century)]: Monohrafiia. Rivne: vydavets O. Zen. 530 s. [in Ukrainian].

Sukhomlynskyi, V. O. (1976). Sto porad uchytelevi [One hundred tips for teachers]. Vybrani tvory: $\mathrm{v} 5$ t. Kyiv: Radianska shkola. T. 2. S. 419-654. [in Ukrainian].

Liubar, O. O., Stelmakhovych, M. H., Fedorenko, D. T. (2006). Istoriia ukrainskoi shkoly i pedahohiky [History of the Ukrainian school and pedagogy: textbook]: navch. posib. Kyiv: Znannia. 647 s. [in Ukrainian].

Dubaseniuk, O. A. (2011). Uprovadzhennia osvitnikh innovatsii v systemi vyshchoi osvity [Introduction of educational innovations in the system of higher education]. Innovatsii u vyshchii osviti: problemy, dosvid, perspektyvy: monohrafiia / za red. P. Yu. Saukha. Zhytomyr: Vyd-vo ZhDU im. I. Franka. S. 62-91. [in Ukrainian].

Kyivskyi universytet im. B. Hrinchenko [Borys Grinchenko Kyiv University]: vebsayt. URL: https:// studfile.net/preview/5110217/page:4/ (data zvernennya: 23.12.2020). [in Ukrainian].

Sukhomlynskyi, V. O. (1964). Pratsia, poklykannia, shchastia [Work, vocation, happiness]. Molod Ukrainy. 3 chervnia. [in Ukrainian].

Sorochynska, T. A. (2021). Profesiina pidhotovka vchytelia na Rivnenshchyni v konteksti osvitnikh reform 1939-1964 rokiv [Teacher training in Rivne region in the context of educational reforms of 1939-1964 years]: monohrafiia. Rivne: vydavets O. Zen. 234 s. [in Ukrainian].

Дата надходження до редакиіï: 02.04.2021 p. 